\title{
ARTICLE
}

\section{Air Pollution in Kolkata: Emerging Challenges and Dynamics}

\section{Joy Karmakar*}

Department of Geography, Serampore College, Hooghly

\begin{tabular}{|c|c|}
\hline ARTICLE INFO & ABSTRACT \\
\hline Article history & \multirow{10}{*}{$\begin{array}{l}\text { In } 2016 \text { WHO reported that Kolkata is the second most polluted city in } \\
\text { India behind Delhi. Albeit the number of registered vehicles in Kolkata } \\
\text { is much less compare to Delhi. Kolkata has encountered a decade long } \\
\text { battle against change of old vehicles and fuel types. So, this paper made } \\
\text { an attempt to explore the dynamics of air pollution in the city specially } \\
\text { pre and post period of vehicle and fuel change in the city. The objectives } \\
\text { of the paper include looking at spatiotemporal change of air pollution in } \\
\text { the city. Besides, the paper additionally illuminates on the role of land } \\
\text { use functions and pollution in the city. The analysis shows that after the } \\
\text { implementation of regulatory measures air pollution in the city reduced to } \\
\text { some extent but effects of the measure gradually diminished. It is found } \\
\text { that land use function as well as dynamics of metropolitan area plays cru- } \\
\text { cial role in the air pollution of the city. }\end{array}$} \\
\hline Received: 27 July 2020 & \\
\hline Accepted: 10 August 2020 & \\
\hline Published Online: 30 September 2020 & \\
\hline Keywords: & \\
\hline Air pollution & \\
\hline Regulatory measure & \\
\hline & \\
\hline Metropolitan area & \\
\hline Spatial and temporal change & \\
\hline
\end{tabular}

\section{Introduction}

$\mathrm{I}$ ndian cities are profoundly polluted spaces. Measures of air quality in Indian urban areas show hazardously elevated levels of toxins and synthetics present noticeable all around. Concentrations of particulate matter are multiple times the levels in U.S. cities ${ }^{[1]}$ and carbon monoxide, nitrogen oxides and benzene frequently far surpass the safety limits suggested by the World Health Organization (WHO). While there are several sources of this pollution, including industries in urban area, household fuel choices and the indiscriminate burning of leaves and other waste by municipal workers, vehicular pollution has come to be perceived as a main contributor ${ }^{[2]}$. World health organization identified six "classic" air pollutants generated from vehicular sources. These are lead, suspended particu- late matter ${ }^{\Phi}(\mathrm{SPM})$, ozone, carbon dioxide, sulfur dioxide and Nitrogen dioxide. There are two significant fountains of vehicular contamination: First, the financial boom after 1990s joined with an insufficiency of public transport has prompted fast development in the sales of motorized vehicles. Second, most Indian cities are serviced by an ageing fleet of public and commercial vehicles, whose poor emissions attributes are aggravated by utilization of poor quality or debased fuel. An ongoing report by the Central Pollution Control Board in India expresses that 60 percent of vehicular pollution is inferable from vehicles that are more than 10 years of age and these form under 30 percent of the total populace of engine vehicles. Kolkata as one of the megacity in India also encounters poor air quality.

(1) The WHO places special emphasis on suspended particles smaller than 10 microns $(\mu \mathrm{m})$ in diameter (PM10), also called inhalable particulate matter, and those smaller than $2.5 \mu \mathrm{m}$ (PM2.5), called fine or respirable particulate matter

*Corresponding Author:

Joy Karmakar,

Department of Geography, Serampore College, Hooghly;

Email: joykarmakar49@gmail.com 
In August 2003, based on Central Pollution Control Board (CPCB) data, the Supreme Court noted that the Respirable Particulate Matter (RSPM) levels in various Indian cities including Kolkata are alarming and directed the $\mathrm{CPCB}$ to work with local regulatory bodies to develop action plans to improve air quality. An investigation was completed with help from the Asian Development Bank (ADB) to survey the source of respiratory particulate matter in Kolkata in 2003. This investigation has anticipated that the respirable particulate outflows from vehicles, street dust, other area sources and industry will develop from an expected 75,140 to 136,796 tons for each year in 2014 if critical endeavors are not made to decrease emanations. It is likewise discovered that the most noteworthy outflows of suspended particulate matter (SPM) and $\mathrm{PM}_{10}$ have been seen at Kolkata. This could be because of the increased number of vehicles enrolled.

After years of legal and political bottlenecks, the Calcutta High Court also passed a judgment on July 18, 2008 , ushering in a new regulatory regime for the city's transport system. All vehicles 15 years or more seasoned were restricted from the avenues and all auto-rickshaws were required to have 4-stroke motors that run uniquely on LPG. Following wide-spread viciousness in the city of Kolkata in January 2009 and requests from the state government, the court allowed a six-month augmentation until July 1, 2009. After several appeals and disagreements making a course for execution and when it occurred, was rushed as opposed to arranged. The city moved to LPG instead of compressed natural gas $(\mathrm{CNG})$ which was known to have superior ignition properties and incite less damage to motor engines ${ }^{[3]}$. Therefore, maintaining good air quality in urban areas are not so linear rather a complex one. For instance, the imposition of fuel and vehicle emission standard can rise capital and operating expenses for transport operators. This may lead to the service unaffordable by poor users. So, transport policies have to be designed taking into considerations of environmental implications and public and private affordability. With this background the paper made an attempt to investigate whether the level of air pollution in Kolkata really reduced or remain as it was earlier even after change of fuel and engine of car. It is believed that several different dimensions in land use planning can also influence urban air quality. These dimensions of land use planning are inclusive of density, structure, diversity etc. ${ }^{[4,5]}$. Scholars showed that positive correlation exists between urban built up area and level air pollution. Thermal variations in urban area are also the results of different land use and land cover classes ${ }^{[6,7]}$. In this paper I examined the differences of air quality between the various measuring stations spanned across the city and air quality in different land use zones of the city. Moreover, the paper also analyzes the policies of late introduced to deal with the situation.

The following section provides the data, methodology and details of the site. Thereafter, air quality of the city is analyzed across spatial and temporal scale along with influence of land use function in the city. Then various policies introduced off late related to curbing air pollution are examined and in the last section concludes with some recommendations.

\section{Data Base and Methodology}

The Kolkata Municipal Corporation (KMC) covers an area of $187.3 \mathrm{~km}^{2}$ and comprises of 141 wards extended to 15 boroughs. As per Census of India (2011), population of $\mathrm{KMC}$ in 2011 is 4,496,694. Density of the population in the city is 24,252 per sq. $\mathrm{km}$. The city is situated along the banks of the Hooghly River. Temperature of the city ranges from $10^{\circ} \mathrm{C}$ to $40^{\circ} \mathrm{C}$.

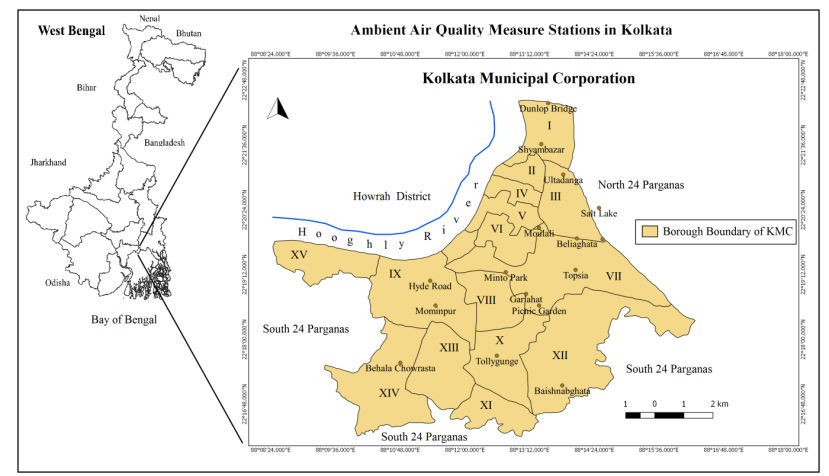

Figure 1. Kolkata Municipal Corporation (KMC) featuring Air Quality Monitoring Stations

It is a state capital and the only million plus city in the state of West Bengal. Air quality monitoring stations in the city are spread across the north, south, east and west part of the city. It is worthwhile to note here that to regulate pollution in the city in 2008 Calcutta High Court passed an ordered to change the vehicles engine and fuel.

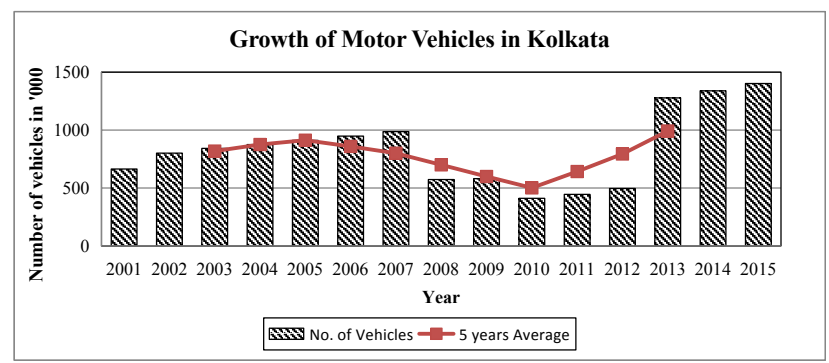

Figure 2. Growth of Motor Vehicles in Kolkata

Registered vehicles in the city sharply declined after the court order as evident in Figure 2; however number of cars 
registered afterwards almost double. Though, more than fifty percent people used public transport as a mode for mobility in the city. In other words, car and two wheelers used only 10 percent of the people in the city ${ }^{[8]}$. Studies also show the positive relationship between increasing traffic volume and increasing pollution levels. A rough estimate indicate that per 1000 increase in traffic volume lead to an increase in $\mathrm{NO}_{\mathrm{x}}$ level by 12.5 microgram per cubic meter, 150 microgram per cubic meter of SPM and 15.4 microgram per cubic meter of Hydro-carbon. In fact earlier studies in Kolkata showed that the highest polluting group is taxis of which 50 percent violates emission norms. Truck and private cars occupy second and third place with 39.2 percent violations and 32.6 percent violations respectively ${ }^{[9]}$. Therefore, growing numbers of vehicles in the recent years in city is a major concerned and argued one of the main contributors of the air pollution in the city.

The ambient air quality monitoring network includes estimation of various air toxins at various vital areas in the city. The West Bengal Pollution Control Board (WBPCB), under the direction of National Air Monitoring Program (NAMP), routinely screens ambient air quality of KMC. During the year 2017-2018, the board checked air quality in the district of Kolkata at 17 stations. Pollutants enter the cities as gases, particles, or as vaporizers, by dissipation of fluids or by co - evaporation of dissolved solvents from water and by wind erosion. Significant air toxins in Indian cities are Sulfur dioxide $\left(\mathrm{SO}_{2}\right)$, suspended particulate matter, and nitrogen dioxide $\left(\mathrm{NO}_{2}\right)$. It is worthwhile to mention that in West Bengal only 4 stations measure the 12 parameters notified under National Ambient Air Quality Standard and rest of the stations (62 stations extend all over West Bengal) measure only three parameters i.e. $\mathrm{SO}_{2}$, $\mathrm{NO}_{2}$ and $\mathrm{PM}_{10}$. For the purpose of this study 17 stations of KMC have been taken for analysis and all these station record above mentioned three standard parameters of air quality ${ }^{\circledR}$. Moreover air quality data of 2008-09 is also taken for the analysis to understand temporal change in air quality of the city.

Based on the three parameters Air quality index (AQI) developed by Swamee and Tyagi ${ }^{[10]}$ in 1999 has been used. AQI is determined by the following equation.

$\left.\mathrm{I}=\left(\sum_{\mathrm{i}=1}^{\mathrm{n}}(\mathrm{AQI})_{\mathrm{i}}\right)^{\mathrm{p}}\right)^{1 / \mathrm{p}}$

Where, $\mathrm{I}$ is the aggregate AQI

$A Q I_{i}=$ the sub-index for $i^{\text {th }}$ pollutant, and $p=a$ constant i.e. 2.5 as per Swamee and Tyagi.

(1) The checking of contaminations in these stations was completed for $24 \mathrm{~h}$ (four-hourly sampling for gaseous pollutants and eight-hourly sampling for particulate matter) with a recurrence of two times every week to have 104 perceptions in a year.
The sub index for $\mathrm{i}^{\text {th }}$ pollutant are measured through following equation

$$
\mathrm{AQI} \mathrm{I}_{\mathrm{i}}=\sum_{i=1}^{N}\left((S i / q)^{m}\right)
$$

Where, $\mathrm{Si}=$ sub-index, $\mathrm{q}=$ constant and $\mathrm{m}=$ constant

Since each of the constant varies with the pollutant following table is showing the details of the constant value

Table 1. Sub-index Constants

\begin{tabular}{|c|c|c|c|}
\hline Pollutants & Units & q & m \\
\hline Nitrogen dioxide & $\mu \mathrm{g} / \mathrm{L}$ & 3.75 & 0.94 \\
\hline Sulphur dioxide & $\mu \mathrm{g} / \mathrm{L}$ & 2.62 & 0.81 \\
\hline $\begin{array}{c}\text { Suspended particulate } \\
\text { matter 10 }\end{array}$ & $\mu \mathrm{g} / \mathrm{L}$ & 1.00 & 0.87 \\
\hline
\end{tabular}

Source: Swamee and Tyagi, 1999.

After the formulation of Air Quality Index (AQI) 17 stations have been categorized to test two hypotheses. The first hypothesis is that there is no difference of level of air pollution in the center and outer part of the city. The second hypothesis is that there is no difference of pollution among different land use of the city. To test the first hypothesis Mann-Whitney $\mathrm{U}^{(2)}$ tests is used. The Null Hypothesis is that there is no difference of level air pollution between stations located at the centre and peripheries of the city. Following is the formula of U statistics ${ }^{[1]}$.

U test statistic $=\sum \mathrm{r}-\left(\mathrm{n}_{\mathrm{r}}{ }^{*}\left(\mathrm{n}_{\mathrm{r}}+1\right) / 2\right.$

Moreover, to test second hypothesis Kruskal-Wallis $\mathrm{H}$ statistics has been applied. The null hypothesis is that there is no difference of air pollution level in the residential, commercial, industrial and mixed use area of the $\mathrm{KMC}$. Following is the formula of $\mathrm{H}$ statistics

$\mathrm{H}$ test statistic $=\frac{12}{N(N+1)}\left[\sum R^{2} / n\right]-3(\mathrm{~N}+1)$

Where, $\mathrm{N}=$ total sample size, $\mathrm{n}=$ the sample size of a particular sample, $\mathrm{R}=$ sum of the ranks of the particular sample, $R^{2}=$ square of the $R, \sum R^{2} / n=$ for each of the $k$ samples quantity $R^{2} / n$ is calculated then sum of these $k$ quantities is taken.

\footnotetext{
To begin with, the observations are arranged in ascending order in regard of the variable and their positions (R) are assigned (smallest value assigned rank 1, second rank 2 and so on). The subsequent advance includes arranging the observations' rank scores as per the sample or group to which they belong. The rank scores are added for these two groups of observations and the smaller total is assigned $\sum \mathrm{r}$. The estimation of this amount is inserted into the equation for the test statistic along with $\mathrm{nr}$ - the number of observations in the group that provides $\sum \mathrm{r}$.
} 
The following table 2 shows the air quality monitoring stations under different categories of location and its associated land use functions in the city. Only four major land use functions have incorporated for the analysis. These are residential, industrial, and commercial and mixed use. It is worthwhile to note that each of the land use function have taken into consideration for analysis due to its potential to produce air pollution.

Table 2. Classifications of the Air Quality Monitoring Stations

\begin{tabular}{|c|c|c|c|c|c|}
\hline Stations & Location & Land use & Stations & Location & Land use \\
\hline $\begin{array}{c}\text { Dunlop } \\
\text { Bridge }\end{array}$ & Edge & $\begin{array}{c}\text { Industri- } \\
\text { al }\end{array}$ & Baishnabghata & Edge & $\begin{array}{c}\text { Residen- } \\
\text { tial }\end{array}$ \\
\hline Picnic Garden & Central & $\begin{array}{c}\text { Residen- } \\
\text { tial }\end{array}$ & Ultadanga & Edge & Industrial \\
\hline Tollygunge & Central & Mixed & Mominpur & Central & Industrial \\
\hline Hyde Road & Edge & $\begin{array}{c}\text { Industri- } \\
\text { al }\end{array}$ & Moulali & Central & $\begin{array}{c}\text { commer- } \\
\text { cial }\end{array}$ \\
\hline $\begin{array}{c}\text { Behala Chow- } \\
\text { rasta }\end{array}$ & Edge & $\begin{array}{c}\text { Residen- } \\
\text { tial }\end{array}$ & Shyambazar & Central & $\begin{array}{c}\text { commer- } \\
\text { cial }\end{array}$ \\
\hline $\begin{array}{c}\text { Beliaghata } \\
\text { Central }\end{array}$ & Mixed & Gariahat & Central & $\begin{array}{c}\text { commer- } \\
\text { cial }\end{array}$ \\
\hline Salt Lake & Edge & $\begin{array}{c}\text { Residen- } \\
\text { tial }\end{array}$ & Minto Park & Central & $\begin{array}{c}\text { commer- } \\
\text { cial }\end{array}$ \\
\hline Topsia & Central & Mixed & $\begin{array}{c}\text { Paribesh Bha- } \\
\text { van }\end{array}$ & Edge & $\begin{array}{c}\text { Residen- } \\
\text { tial }\end{array}$ \\
\hline
\end{tabular}

Source: Compiled by the author.

Locational categories are done precisely on the basis of their relative location (from centre) in the city while land use category of the location are done based on recent classification of the land use of the city ${ }^{[12]}$. Though it is always difficult to draw sharp lines of demarcation between various lands uses in the city noted even perspective plan prepared by KMDA ${ }^{[13]}$.

\section{A Spatial and Temporal Comparison of Air Pollution in the City}

Kolkata is the third most polluted city as far as nitrogen oxide (NOx) levels and twelfth most contaminated city as far as $\mathrm{PM}_{10}$ levels as per the announcement given by Ministry of Environment and Forests to Lok Sabha in August $2010^{[14]}$. However, air quality varies across areas in Kolkata just as it vacillates every year. The pollution concentration in Kolkata is an element of blending profundity, wind speed, and physical size of the city. The occasional variety is likewise impacting the concentration of pollution in the city. The concentration of particulate toxins during winter is moderately higher than the remainder of the year in Kolkata (India). It is a result of the longer residence time of particulates in the environment, during winter because of low breezes and low blending height. In fact, air quality in Kolkata and it surrounding districts remains poor in winter and improves slightly in summer. Kolkata is noted for high use of diesel, to the extent that it has earned the designation of being the "diesel capital of the country". Harmful emissions from diesel vehicles are a huge concern in the city. Diesel vehicles contribute most extreme to the particulates, nitrogen oxides; harmful hydrocarbons that are the major concern for the quality of air in Kolkata. As indicated by CPCB assessment 55 percent of vehicles in Kolkata are diesel-driven ${ }^{[15]}$. While every commercial vehicle including the taxi runs on diesel, a significant number of these were also old. At present, the share of diesel vehicles is increasing. The World Bank examination of 2004 has surveyed that diesel ignition in the city can contribute essentially to the total $\mathrm{PM}_{2.5}$ levels. During winter the proportion can go as high as 62 percent of the PM2.5 loads ${ }^{[16]}$. The following maps shows change of $\mathrm{NO}_{2}, \mathrm{SO}_{2}$ and $\mathrm{PM}_{10}$ between the year 2009 and 2018 across the different stations in the city.

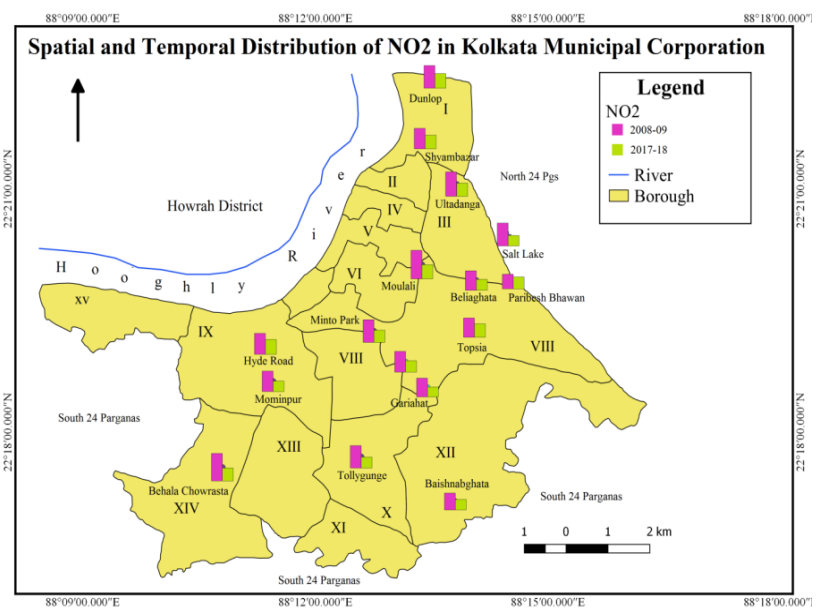

Figure 3.

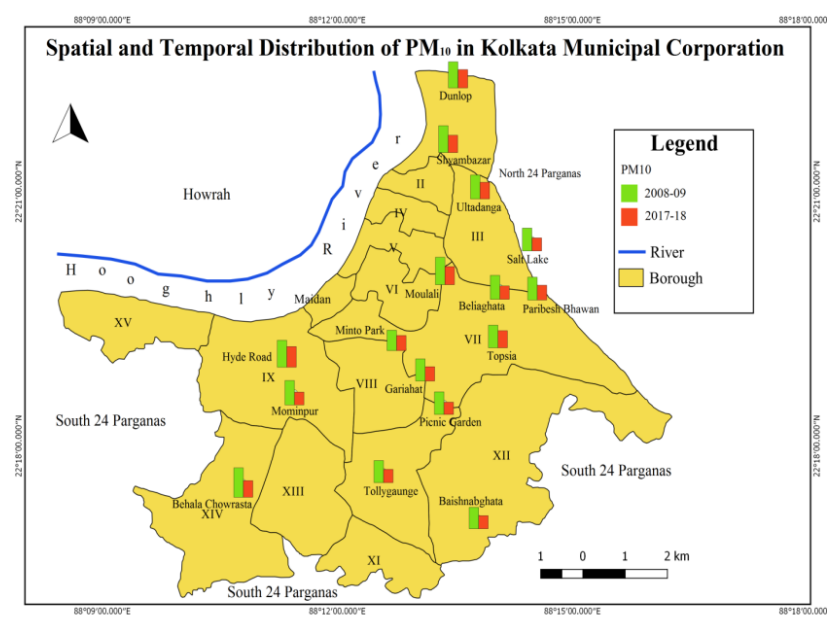

Figure 4. 


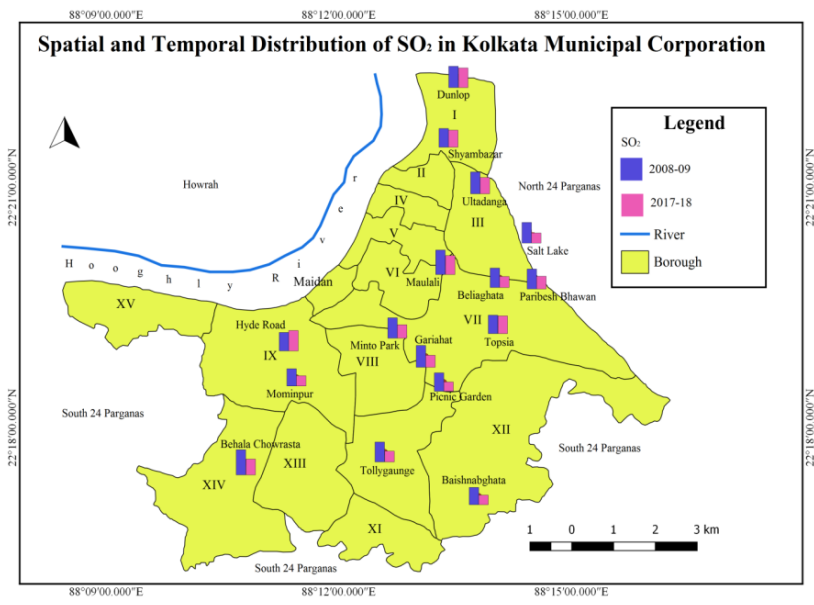

Figure 5.

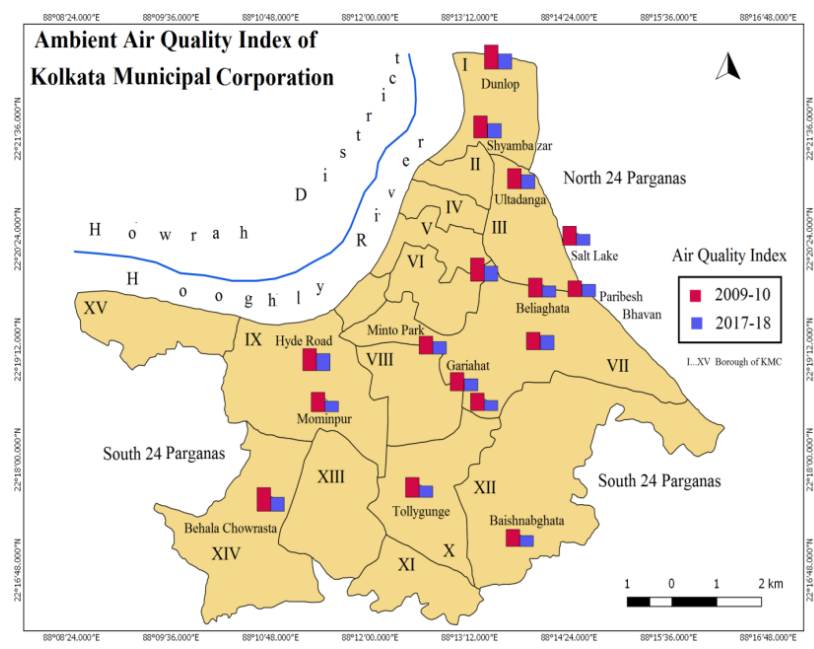

Figure 6.

Spatial distribution of the pollutants (Figure 3, 4 and 5 ) in $\mathrm{KMC}$ is also shows that level of air quality varies across the 17 stations. $\mathrm{NO}_{2}$ was higher in 2008-09 in stations like Moulali, Ultadanga, Behala Chowrasta, while in 2017-18 the amount of $\mathrm{NO}_{2}$ emission has reduced almost 50 percent across the 17 stations. Likewise $\mathrm{PM}_{10}$ emission in 2008-09 was higher at stations like Dunlop Bridge, Hyde Road, Behala Chowrasta, Moulali and Shyambazar. Emission of these stations reduced almost half after a decade. Similarly $\mathrm{SO}_{2}$ emission was remain higher in stations like Dunlop Bridge, Moulali, Ultadanga, Salt Lake and Gariahat in 2008-09. In 2017-18 emission of $\mathrm{SO}_{2}$ reduced in 10 stations but it remain higher in stations like Dunlop Bridge, Hyde Road, Moulali and Topsia. This improvement of air quality in the city is due to the various reasons inclusive of actions on vehicles and its fuel, regulation and shifting of industries. Moreover, it is found that there is an overall improvement of air quality. The above figure 6 shows the spatial and temporal change of air quality across 16 stations. Air quality index improves in all the stations ranging from 3 percent to 7 percent fall or improve across the 16 stations from 2008-09 to 201718 depicted in the figure 7 .

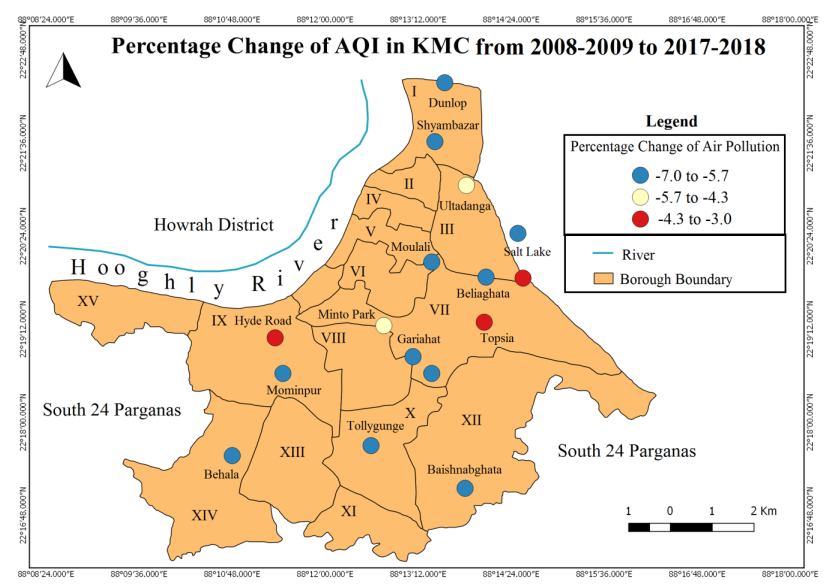

Figure 7.

It is evident from the above figure 7 that air quality index improves in all stations however; the improvement varies across the 16 stations. Out of 16 stations only four stations improve moderately inclusive of Hyde Road, Ultadanga, Topsia, and Paribesh Bhavan. 10 stations air quality index improves relatively higher and these stations include Behala Chowrasta, Tollygunge, Mominpur, Baishnabaghata, Gariahat, Minto Park, Beliaghata, Shyambazar, and Dunlop Bridge. As noted earlier that one of the significant factors that lies behind the improvement of the ambient air quality is the reduction of vehicular emission ${ }^{\mathbb{}}$. Nonetheless, registered vehicles increase twice in the city. So, change of vehicle engine and fuel became effective in the city.

Due to change of fuel and old vehicles, the air quality of the city improved gradually however, this improvement is not uniform across the monitoring stations as pointed out in figure 7. So to explore this arguement, "U" statistics is used and the Null Hypothesis is that there is no difference of air quality between monitering stations located at the centre and edge of the city.

Table 3. U Statistics Testing Air Quality between Centre and Periphery Stations

\begin{tabular}{|c|c|}
\hline Year & Calculated Value \\
\hline 2007 & $38^{*}$ \\
\hline 2017 & $30^{*}$ \\
\hline
\end{tabular}

Source: Calculated by author, 2020, *tabulated value 53 at $5 \%$ level of significance and 57 at $2 \%$ level of significance.

(1) Shifting of industries from inner city to city periphery started in Kolkata since 1996 through apex court order. Mainly tanneries of Kolkata were shifted to Bantala area. It was done reluctantly. 
From the table 3 it is evident that null hypotheses is not rejected which means that level of air quality does not varies across the centre and peripheral monitoring stations of the city. No significant variation of the air quality in the centre and edge stations indicates that peripheral areas of the city is also growing fast ${ }^{[17] \mathbb{Q}}$. This growth is often the results of family migration from adjacent areas or from other areas within the state ${ }^{[18]}$. Some of the edge areas are recently incorporated into KMC. This areas are often encounters lack of public transport. The multi story housing developed in these area are with large parking facilities at the ground floor.

\section{Land Use and Air Pollution in the City}

As a rule, compact (that is mixed-use and high-density) urban structure is contrarily corresponded with auto reliance and positively correlated with the utilization of public transit and strolling, and along these lines the alleviation of air contamination ${ }^{[19]}$. The connection between urban structure and air contamination has been evaluated empirically using a variety of methodologies, especially in relation to developed countries ${ }^{[20]}$. McCarty and Kaza (2015) explored the relationship between several urban landscape metrics and AQI in the U.S., associating sprawling and fragmentary urban spatial structure with lower air quality ${ }^{[21]}$. Stone (2008) evaluated the relationship between urban structure and $\mathrm{O}_{3}$ levels in 45 large U.S. metropolitan areas, finding that excessive $\mathrm{O}_{3}$ levels were bound to happen in decentralized metropolitan areas than in spatially compact metropolitan regions ${ }^{[22]}$. Similar conclusions were drawn by Schweitzer and Zhou (2010) in their investigation of neighborhood-level $\mathrm{O}_{3}$ concentration in 80 U.S. metropolitan districts ${ }^{[23]}$. Mansfield et al. (2015), and Hixson et al. (2010), have both researched the effects of different development scenarios on $\mathrm{PM}_{2.5}$ fixations, coming to the same conclusion that compact development diminished these concentrations, while sprawling development increased them ${ }^{[24]}$. An investigation by Bechle et al. (2011) measured the impacts of urban structure on $\mathrm{NO}_{2}$ concentrations for 83 cities globally, finding a negative relationship between urban contiguity and $\mathrm{NO}_{2}$ focuses, and no statistically significant correlation between compactness and $\mathrm{NO}_{2}$ concentrations ${ }^{[25]}$. Conversely, Borrego et al. (2006) inferred that compact urban morphology with mixed land uses assisted with bringing down $\mathrm{NO}_{2}$ concentrations ${ }^{[26,27]}$.

(1) Rapid growth of Kolkata's periphery is a recent phenomenon primarily after 1990s. it is worthwhile to mention here that Beery and Kasarda (1977) in their paper noted that around the periphery of the city were to be found poorest residents of the city, the schedule caste and refuges from East Bengal. With the passage of time these areas changed
Basic structure of the Kolkata's land use was laid out during the imperial rule and major elements of the city land use were associated with port function, the functions of central business and administrative region, the whole sale market area and European and native residential area. In the post-independence period the city has grown impulsively in south primarily and later in east and south east direction.

It is argued that Kolkata's 'compact city' structure is a bit of leeway: Very high level of strolling, cycling and public vehicle trips are an impression of the manner in which the city is planned. Dense and closely built structures diminish travel separations and make the city progressively walkable. It is hence not an unexpected that 60 percent of the total trips produced in the Kolkata Metropolitan Area have a normal separation of less than 3-4 km. This makes strolling, cycling, para-travel and public vehicle very alluring and possible ${ }^{[28]}$. In fact, the Census 2011 for Kolkata revealed that astounding 89 per cent people of the city walk and use public transport. More than onefourth of the working population is commute to work on foot; nearly one-third work from home. Nearly half of the working population commutes by bus, bicycle and train. The rest commute by private mode and other modes. Though, the new improvement in suburbia is turning out to be sprawl and gated with poor public transport network.

$\mathrm{H}$ statistics is used to see whether the land use function at all influence the level of air pollution in the city or not. A null hypothesis is that there is no difference of air pollution level in different land use zones of the city. So in other words we are assuming that different land use functions of the city emanates similar amount of pollutants in the air.

Table 4. H Statistics Testing Air Quality at Different Land Use Function

\begin{tabular}{|c|c|}
\hline Year & Calculated Value \\
\hline 2007 & $84.16^{*}$ \\
\hline 2017 & $49.02 *$ \\
\hline
\end{tabular}

Source: Calculated by author, 2020, *tabulated value 7.81 at $5 \%$ level of significance and 11.35 at $1 \%$ level of significance.

From the table 4 it is evident that the null hypothesis is rejected and alternative hypotheses are accepted. Therefore, it is clear that different land use function in the city produces different amount of pollutants as a result air quality varies across the monitoring station. For example Hyde road and Baishnabghata area located in the edge of KMC but air pollution level in Hyde road is more compare to Baishnabghata because the former area comes under industrial zone while latter falls in the residential area. Similarly Dunlop Bridge and paribesh bhavan both are located at the edge of the city but proliferate differ- 
ent amount of air pollutant due to its land use functions. Dunlop Bridge is located close to a thermal power plant and many other small industries so air quality in that area remains poor. On the other hand air quality of paribesh bhavan is relatively better due to its location in the residential zone. Following table 5 shows the average AQI at different land use zones in the city.

Table 5. Mean AQI at Different Land Use Zones in Kolkata

\begin{tabular}{|c|c|c|}
\hline Land use Functions & $\mathbf{2 0 1 7}$ & $\mathbf{2 0 0 7}$ \\
\hline Residential & 109.92 & 188.36 \\
\hline Industrial & 134.94 & 200.30 \\
\hline Commercial & 127.87 & 175.56 \\
\hline Mixed use & 115.30 & 181.63 \\
\hline
\end{tabular}

Source: Calculated by author, 2020.

An overview of the table 5 suggests that air quality was poor and very poor in industrial and residential as well as mixed use zones. It is improved over the decades. Maximum improved of air quality occurred in the residential zones in the city. One of the significant reasons behind the improvement is the use of electricity for household lighting and use of LPG as cooking fuel. As per census 2011, more than 96 percent household in the city use electricity for lighting and more than 64 percent people use liquefied petroleum gas (LPG). At the same time more than 24 percent household still use kerosene as cooking fuel, which is one of the prominent sources of air pollution at the household level.

\section{Emerging Challenges and Policy Interven- tion}

Despite the fact that the degree of air contamination diminished somewhat yet new difficulties are likewise experienced by the city. The International Institute for Applied Systems Analysis (IIASA) in Austria and the Council on Energy, Environment, and Water (CEEW) in New Delhi reported that Indian citizens are likely to breathe air with high concentrations of suspended particulate matter $\left(\mathrm{PM}_{2.5}\right)$ in 2030, even if India were to comply with its existing pollution control policies and regulations. In addition they noted that the Indo-Gangetic plain, covering parts of states such as Uttar Pradesh, Bihar, and West Bengal, has the highest population exposure to significant $\mathrm{PM}_{2.5}$ concentrations ${ }^{[29]}$. Kolkata is one of the megacities situated in the Indo-Gangetic plain where people are exposed to high amount of $\mathrm{PM}_{2.5}$. A 2016 World Health Organization (WHO) reports exhibited Kolkata was the second-most polluted Indian city, behind Delhi ${ }^{[30]}$. In 2019, a day after Diwali and Kali Puja, the Air Quality Index (AQI) near the Victoria Memorial was 282. The area is considered as lungs of the city. Likewise, the AQI at Rabindra sarabar and Eastern Command headquarters in the city recorded 345 and 333 respectively. It was shocked the environmentalist because AQI in these stations normally remain moderate.

Shockingly, Kolkata and its metropolitan areas including Howrah, Hooghly, North 24 Parganas, South 24 Parganas and Nadia have far less vehicles and ventures contrasted with the National Capital District (NCR), and blasting of sparklers during Diwali is likewise less. Notwithstanding, Kolkata remains among the most contaminated cities throughout the year in India consistently. The explanation for the city being so contaminated is the widespread utilization of kerosene blended diesel via auto rickshaw drivers in Kolkata Metropolitan Areas (KMAs) like Hooghly, Howrah, North 24 Parganas, South 24 Parganas and parts of Nadia. In Kolkata, the greater part of the auto rickshaws employ on LPG cylinders which is profoundly polluting since it contains about 60 percent butane and 40 percent propane ${ }^{[31]}$. Other than that, the most disturbing fact is about 50,000 illicit 'Vano' (automated vans) are running on kerosene oil, which is extremely risky and exceptionally polluting. In the suburbia, Vano are running on the streets, and nobody minds enough to hold onto these profoundly contaminating vehicles noted by the city environmentalist ${ }^{[32]}$.

In January 2019, the government launched the National Clean Air Program (NCAP), a five-year activity intend to control air contamination, fabricate a pan-India air quality checking system, and improve resident awareness. The program centers around 102 contaminated Indian cities and intends to diminish $\mathrm{PM}_{2.5}$ levels by $20-30$ percent throughout the following five years. Under this program they have identified "non-attainment cities" and Kolkata is one of the top most non-attainment cities in their list. To attain clean air in city some of the following suggestion has been made.

A real time data needs to be generated through mobile application and the application permits a user to rapidly and effectively produce straightforward reports about particular industry and its type ${ }^{\mathbb{Q}}$. Moreover, non-attainment cities require broad planation drive at polluting hotspot areas inclusive of traffic intersections, industrial zones, pathways, dust prone areas. Specialized plants have to be

\footnotetext{
(1) West Bengal State Pollution Control board categorizes industry into five types inclusive of red, orange, green and white types. In red and orange category there are 74 and 19 industry listed respectively. While in case of green and white category there are 67 and 37 industry listed. Beyond these four categories there is an exempted category of industries. Red and orange category of industries cannot be set up in Kolkata Metropolitan Areas (KMA).
} 
planted not only to purify air but also to improve health. Pollution abatement policies have to be implemented such as stringent norms for fuel and vehicles, fleet modernization, electric vehicle policies, and use of clean fuels etc. Mechanical sweeping and watering on road has to be done to control the dust in the city. In addition, specific guidelines and protocols have to be made to monitor and manage indoor pollution in the city. To implement this State Action Plan for Air Pollution has to be formulated.

\section{Conclusion}

This paper made an endeavor to examine the elements of urban air quality in Kolkata. There were a few difficulties in the last decade to control vehicle discharge and keep environment clean in the city. A portion of the administrative measures have been executed exclusively in the KMC however at metropolitan level administrative estimates remains unimplemented. Despite the fact, that air contamination in the city diminished for time being because of administrative measure however, it indeed began to increment. The paper likewise noticed that air quality in the city fluctuates over the diverse land use zones rather than center and edge of the city.

\section{Conflicts of Interest}

The author declares no conflicts of interest.

\section{Availability of Data}

All the data are accessed from online and available in government website and can be provided if required

\section{References}

[1] Greenstone, M., Rema, H. Environmental regulations, air and water pollution and infant mortality in India, NBER Working Paper 17210, 2011.

[2] Ghose, M. R. Paul, Banerjee, K.S. Assessment of the impacts of vehicular emissions on urban air quality and its management in Indian context: the case of Kolkata (calcutta), Environmental Science \& Policy, 2004, 7(4).

[3] Ghosh, P., Somanathan, R. Improving Urban Air Quality in India Lessons from the Kolkata Clean Air Regulations of 2009, Working paper, International Growth Centre, London, 2013.

[4] Tolley, G. Cohen, A. Air pollution and urban land use policy, Journal of Environmental Economics and Management, 1976, 2(4).

[5] Weng, Q., Yang, S. Urban air pollution pattern land use and thermal landscape: an examination of linkage using GIS, Environmental Monitoring and Assess- ment, 2006, 117: 463-489.

https://doi.org/10.1007/s10661-006-0888-9

[6] Nichol, J. E. High resolution surface temperature patterns related to urban morphology in a tropical city: A satellite bases study, Journal of applied Meteorology, 1996, 35(1).

[7] Balling, R. C., Brazell, S. W. High resolution surface temperature patterns in a complex urban terrain, Photogrammetric Engineering and Remote sensing, 1988, 54(9).

[8] National Transport Development Policy Committee. India Transport Report, Moving India to 2032, Routledge, New Delhi, 2013.

[9] Kolkata Metropolitan Development Authority. Perspective plan of KMA: 2025, KMDA, Kolkata, 2005.

[10] Swamee, P.K., Tyagi, A. Formation of an Air Pollution Index, Journal of the Air \& Waste Management Association, 1999, 49(1): 88-91.

DOI: $10.1080 / 10473289.1999 .10463776$

[11] Matthews, J.A. Quantitative and Statistical approaches to Geography, Pergamon press, Oxford.

[12] Nath, B, Acharjee, S. Urban Municipal Growth and Landuse Change Monitoring Using High Resolution Satellite Imageries and Secondary Data, Studies in Surveying and Mapping Science, 2013, 1(3).

[13] Munshi, S.K. Calcutta: Land, Land use and land market, chapter in books (Ed) Calcutta's Urban future: Agonies from the past and prospects from the future, by Dasgupta, B, Bhattacharya, M. Basu, D. K. Chatterjee, M. and Banerjee, T. K. Government of West Bengal, 1991.

[14] Roy Chowdhury, A. Citizen's report: Air quality and mobility in Kolkata, Centre for Science and Environment, New Delhi, 2011.

[15] Roy Chowdhury, A. Citizen's report: Air quality and mobility in Kolkata, Centre for Science and Environment, New Delhi, 2011.

[16] Gwilliam, K. Kojima, M. and Johnson, T. (2004) Reducing Air Pollution from Urban Transport, the World Bank, Washington DC

[17] Berry, B. J.L., Kasarda, J.D. Contemporary urban ecology, Macmillan, New York, 1977.

[18] Shaw, A. Inner-city and outer-city neighbourhood in Kolkata: Their changing dynamics Post liberalization, Environment and Urbanization Asia, 2015, 6(2): 139-153

[19] Frank, L.D., Sallis, J.F., Conway, T.L. Chapman, J.E., Saelens, B.E. Bachman, W. Many pathways from land use to health: Associations between neighborhood walkability and active transportation, body mass index, and air quality. Journal of American Planning Association, 2006, 72: 75-87. 
[20] Marquez, L., Smith, N. A framework for linking urban form and air quality, Environmental Modeling and Software, 1999, 14(6): 541-548. https://doi.org/10.1016/S1364-8152(99)00018-3

[21] McCarty, J., Kaza, N. Urban form and air quality in the United States. Landscape and Urban Planning, 2015, 139: 168-179.

[22] Stone, B., Jr. Urban sprawl and air quality in large US cities, Journal of Environment Management, 2008, 86(4): 688-698.

[23] Schweitzer, L., Zhou, J. Neighborhood air quality, respiratory health, and vulnerable populations in compact and sprawled regions, Journal of American Planning Association, 2010, 76: 363-371

[24] Mansfield, T.J., Rodriguez, D.A., Huegy, J., Gibson, J.M. The effects of urban form on ambient air pollution and public health risk: A case study in Raleigh, North Carolina. Risk Anal, 2015, 35: 901-918

[25] Bechle, M.J., Millet, D.B., Marshall, J.D. Effects of income and urban form on urban NO2: Global evidence from satellites, Environmental Science Technology, 2011, 45(11): 4914-4919

[26] Borrego, C., Martins, H. Tchepel, O. Salmim, L. Monteiro, A., Miranda, A.I. How urban structure can affect city sustainability from an air quality perspec- tive. Environmental Modeling and Software, 2006, 21: 461-467

[27] Wang, S., Fang, C., Wang, Y. Spatiotemporal variations of energy-related $\mathrm{CO} 2$ emissions in China and its influencing factors: An empirical analysis based on provincial panel data. Renewable Sustainable Energy Reviews, 2016, 55: 505-515.

[28] Roy Chowdhury, A. Citizen's report: Air quality and mobility in Kolkata, Centre for Science and Environment, New Delhi, 2011.

[29] International Institute for Applied Systems Analysis and Council on Energy Environment and Water. Pathways to Achieve National Ambient Air Quality Standards (NAAQS) in India, IIASA and CEEW, New Delhi, 2019.

[30] WHO. Ambient Air Pollution: a global assessment of exposure and burden of disease, World Health Organization, Geneva, 2016.

[31] Nath, S. Why Despite Fewer Vehicles and Industries, Kolkata is Chasing Delhi on Pollution Charts, News 18, 2019. Retrieved from:

https://www.news 18.com/news/india/why-despite-fewer-vehicles-and-industries-kolkata-is-chasing-delhi-on-pollution-charts-2378547 